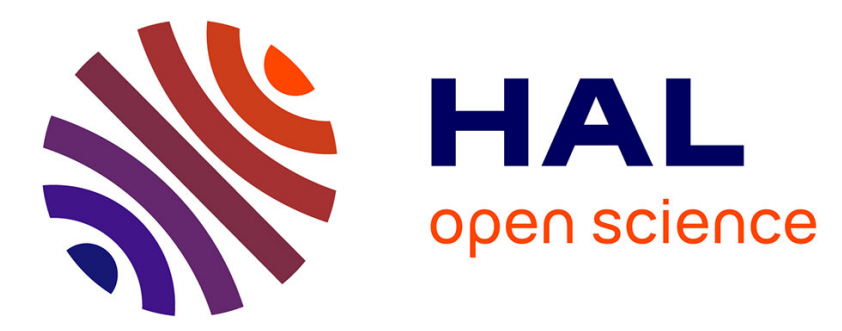

\title{
Bimetallic neutral palladium (II) bis(dithiolene) complex: Unusual synthesis, structural and theoretical study
}

Flavia Pop, Diana-G. Branzea, Thomas Cauchy, Narcis Avarvari

\section{- To cite this version:}

Flavia Pop, Diana-G. Branzea, Thomas Cauchy, Narcis Avarvari. Bimetallic neutral palladium (II) bis(dithiolene) complex: Unusual synthesis, structural and theoretical study. Comptes Rendus. Chimie, 2012, 15 (10), pp.904-910. 10.1016/j.crci.2012.03.007 . hal-03344539

HAL Id: hal-03344539

https://univ-angers.hal.science/hal-03344539

Submitted on 15 Sep 2021

HAL is a multi-disciplinary open access archive for the deposit and dissemination of scientific research documents, whether they are published or not. The documents may come from teaching and research institutions in France or abroad, or from public or private research centers.
L'archive ouverte pluridisciplinaire HAL, est destinée au dépôt et à la diffusion de documents scientifiques de niveau recherche, publiés ou non, émanant des établissements d'enseignement et de recherche français ou étrangers, des laboratoires publics ou privés. 
Full paper/Mémoire

\title{
Bimetallic neutral palladium (II) bis(dithiolene) complex: Unusual synthesis, structural and theoretical study
}

\author{
Flavia Pop, Diana G. Branzea, Thomas Cauchy, Narcis Avarvari* \\ UMR 6200, CNRS, laboratoire Moltech-Anjou, UFR Sciences, université d'Angers, Bâtiment K, 2, boulevard Lavoisier, 49045 Angers, France
}

\section{A R T I C L E I N F O}

\section{Article history:}

Received 2 March 2012

Accepted after revision 20 March 2012

Available online 22 May 2012

\section{Keywords:}

S ligands

Tetrathiafulvalenes

Bimetallic complexes

Structure elucidation

Theoretical calculations

\begin{abstract}
A B S T R A C T
The unusual synthesis of the dimeric dithiolene complex $\left[\left(\mathrm{PPh}_{3}\right) \mathrm{Pd}(\right.$ ethylene-1,2dithiolate) $]_{2}(1)$, containing the simplest dithiolene ligand, has been achieved through the reaction between tetrathiafulvalene (TTF) and $\mathrm{Pd}\left(\mathrm{PPh}_{3}\right)_{4}$. The complex shows a folded structure in the solid state, according to single crystal X-ray analysis performed on crystals grown from two different system solvents and conditions, with a central $\left[\mathrm{Pd}_{2} \mathrm{~S}_{2}\right]$ ring folded about the $S \cdots S$ hinge by $67.9^{\circ}$. The optimized geometry at the DFT level is in excellent agreement with the experimental structure. Moreover, TD-DFT calculations allowed the assignment of the low energy band arising at $576 \mathrm{~nm}$ to the HOMO $\rightarrow$ LUMO transition, between frontier orbitals having mixed metal and dithiolene character.

(c) 2012 Académie des sciences. Published by Elsevier Masson SAS. All rights reserved.
\end{abstract}

\section{Introduction}

Metal-dithiolene complexes have been extensively studied since many years for the elaboration of molecular materials with conducting, magnetic and optical properties [1], their peculiarity coming from the non-innocence of the dithiolate ligands. Indeed, the frontier orbitals of such complexes develop both on the ligands, especially the sulfur atoms, and on the metal centers [2]. This feature, combined with their propensity to engage in intermolecular S...S and metal $\cdots$ S interactions, thus providing excellent stacking properties in the solid state, makes them valuable building blocks for conducting and magnetic materials [3]. In addition, metal bis(dithiolene) complexes in different oxidation states show strong absorption in the near infrared region [4] from $700 \mathrm{~nm}$ (nickel) up to $1.6 \mu \mathrm{m}$ (gold) depending on the nature of the metal and the substitution pattern of the dithiolene ligand [5]. The group 10 (Ni, Pd, Pt) square planar complexes show in the monoanionic or neutral species, very often obtained upon oxidation of the

\footnotetext{
* Corresponding author.

E-mail address: narcis.avarvari@univ-angers.fr (N. Avarvari).
}

initially formed dianionic compounds, these low energy absorption bands, attributed to $\pi-\pi^{*}$ transitions of HOMOSOMO and HOMO-LUMO types, respectively [6]. Accordingly, such complexes have found applications as near infrared photodetectors [7], optical switching devices [8], organic dyes [9], and organic electronics [10].

In the case of the simplest 1,2-dithiolene ligand, e.g. 1,2ethylene-dithiolate $\left(\mathrm{S}_{2} \mathrm{C}_{2} \mathrm{H}_{2}\right)$, also considered as the "parent dithiolene", the crystal structures of the neutral bis(dithiolene) complexes $\left[\mathrm{M}\left(\mathrm{S}_{2} \mathrm{C}_{2} \mathrm{H}_{2}\right)_{2}\right](\mathrm{M}=\mathrm{Ni}, \mathrm{Pd}, \mathrm{Pt})$ show, interestingly, dimeric units formed through $\mathrm{M} \cdots \mathrm{M}$ bonds for Pd and Pt, while the Ni complex consists of isolated monomers [11]. The low energy absorption bands for these "parent complexes", in which the oxidation from the dianion to the neutral species affects mainly the "noninnocent" ligands, appear at $720 \mathrm{~nm}(\mathrm{Ni})$ [5a], $785 \mathrm{~nm}$ (Pd) [5b], and $680 \mathrm{~nm}(\mathrm{Pt})[5 \mathrm{c}]$. Neutral metal mono(dithiolene) complexes $(\mathrm{M}=\mathrm{Ni}, \mathrm{Pd}, \mathrm{Pt})$ can be obtained by formally replacing one dithiolene ligand by two monodentate or one bidentate neutral ligand, such as the phosphines. However, in this case there is no ambiguity on the oxidation state of the components, since the metal is $2+$ and the dithiolene 2-. Accordingly, an extensive series of neutral mono(dithiolene) complexes formulated as 
(P2) M(dithiolene) ( $\mathrm{M}=\mathrm{Ni}, \mathrm{Pd}, \mathrm{Pt})$ have been synthesized, where $\mathrm{P} 2$ stands generally for two $\mathrm{PPh}_{3}$ or one dppe ligands (dppe $=1,2$-bis (diphenylphosphino)ethane) [12]. The colours of these complexes when the dithiolene is maleonitriledithiolate (mnt) vary from brown-red for Ni to orange for Pd and, finally, yellow for Pt, yet large variations are observed upon changing the substitution pattern on the dithiolene ligand. For example, the Pd complex formulated as $\left(\mathrm{Ph}_{3} \mathrm{P}\right)_{2} \mathrm{Pd}\left(\mathrm{S}_{2} \mathrm{C}_{2}(\mathrm{SMe})_{2}\right)$, thus containing the bis(thiomethyl)dithiolene ligand, for which the single crystal X-ray structure was described, was obtained as red-violet crystals [12c]. Note that in all the crystal structures described so far the complexes appear as monomeric units. Generally, the synthesis of these neutral mono(dithiolene) complexes involves either the reaction between the ( $\mathrm{P} 2) \mathrm{MCl}_{2}$ complex with the dithiolate [12e], the displacement of a dithiolene ligand from the neutral bis(dithiolene) complexes by phosphines [12a,b], or the displacement of a cyclooctadiene (COD) from (COD)Pt(dithiolene) by phosphines [12f,g]. However, other more specific methods have been also employed, such as the direct reaction between the $\mathrm{Pd}\left(\mathrm{PPh}_{3}\right)_{4}$ complex and the dimethyltetrathiooxalate in the case of $\left(\mathrm{Ph}_{3} \mathrm{P}\right)_{2} \mathrm{Pd}\left(\mathrm{S}_{2} \mathrm{C}_{2}(\mathrm{SMe})_{2}\right)$ [12c]. To our knowledge, in all but one case [12g], the dithiolene ligand was not the parent one. Surprisingly indeed in this series, only the platinum complex $\left(\mathrm{Ph}_{3} \mathrm{P}\right)_{2} \mathrm{Pt}$ (edt) (edt = 1,2-ethylene-dithiolate) was described as a bright yellow solid, although without any crystal structure analysis [12g].

We describe herein the unexpected synthesis of the $\left[\left(\mathrm{Ph}_{3} \mathrm{P}\right) \mathrm{Pd}(\text { edt })\right]_{2}$ dimeric complex 1, together with its spectroscopic and structural characterization. DFT and TD DFT calculations have been performed in order to support the experimental geometry and to explain the electronic structure of this unprecedented dimeric dithiolene complex.

\section{Results and discussion}

\subsection{Synthesis and characterization}

We noticed initially the formation of the title compound $\left[\left(\mathrm{Ph}_{3} \mathrm{P}\right) \mathrm{Pd}(\mathrm{edt})\right]_{2}(\mathbf{1})$, identified after single crystal $\mathrm{X}$-ray analysis (vide infra), as traces of by-product during our attempts of Stille type coupling between TTF-SnMe ${ }_{3}$ and various halogenated aromatic substrates in the presence of the standard $\operatorname{Pd}(0)$ catalyst $\operatorname{Pd}\left(\mathrm{PPh}_{3}\right)_{4}$ [13]. Puzzled by this observation we decided to rationalize the formation of $\mathbf{1}$ and assumed that the direct reaction between TTF and $\mathrm{Pd}\left(\mathrm{PPh}_{3}\right)_{4}$ would afford $\mathbf{1}$, in the absence of any other obvious reaction paths (Scheme 1 ).

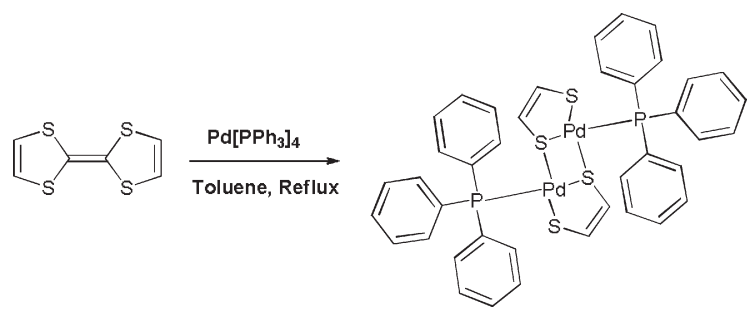

Scheme 1. Synthesis of $\mathbf{1}$.
Indeed, after refluxing during $48 \mathrm{~h}$ an equimolar mixture of TTF and $\mathrm{Pd}\left(\mathrm{PPh}_{3}\right)_{4}$ in toluene, the only product which has been isolated after chromatographic work-up was the dimeric dithiolene complex $\mathbf{1}$. Clearly, the yield of this reaction is low, yet the unreacted TTF is fully recovered, while the excess of palladium complex affords black colloidal palladium together with phosphine and phosphine-oxide. The complex 1 was obtained as an air stable dark violet crystalline solid which was first characterized by spectroscopic methods. ${ }^{31} \mathrm{P}$ NMR spectrum shows a sharp single peak at $30.26 \mathrm{ppm}$, indicative of $\mathrm{PPh}_{3}$ ligands symmetrically coordinated to a Pd-dithiolate fragment [14]. ${ }^{1} \mathrm{H}$ NMR is in agreement with a $1: 1$ ratio between an edt and a $\mathrm{PPh}_{3}$ ligand, although the chemical shift of one of the vinylic protons is somewhat puzzling, since it appears rather shielded, at $4.46 \mathrm{ppm}$, when compared with the other proton at $6.28 \mathrm{ppm}$, the usual value for this type of proton. The explanation for this upfield shift lies very likely in the location of the corresponding proton in the anisotropy cone of one phenyl ring of the $\mathrm{PPh}_{3}$ ligand. This assumption is supported by the crystal structure (vide infra) of the complex, showing clearly the short distance $(2.63-2.65 \AA)$ between the proton and the centroid of one phenyl ring. An important result was the observation of the molecular peak of the dimer in MALDI-TOF, indicating the presence and stability of the species also in solution and not only in the crystal structure.

At the present stage, the formation of $\mathbf{1}$ is hard to explain through a reaction mechanism. One can speculate that in an initial step the unsaturated $\mathrm{Pd}\left(\mathrm{PPh}_{3}\right)_{2}$ fragment, generated by decoordination of two phosphines upon heating, coordinates to the outer double bond of TTF, as it was observed for the $\mathrm{Pt}\left(\mathrm{PPh}_{3}\right)_{2}$ fragment, for which $\eta^{2}$ complexes $\left[\left(\mathrm{PPh}_{3}\right)_{2} \mathrm{Pt}\left(\eta^{2}-\mathrm{TTF}\right)\right]$ and $\left[\left(\mathrm{PPh}_{3}\right)_{2} \mathrm{Pt}\left(\eta^{2}-0-\right.\right.$ $\left.\left.\mathrm{Me}_{2} \mathrm{TTF}\right)\right]$ have been evidenced, including a single crystal $\mathrm{X}$-ray structure for the latter [15]. Interestingly, the coordination of the Pt center took place exclusively to the unsubstituted double bond, thus suggesting that the steric hindrance of the Me groups very likely hampers the $\eta^{2}$ coordination. Accordingly, the initial occurrence in our case of a $\eta^{2}$ complex $\left[\left(\mathrm{PPh}_{3}\right)_{2} \mathrm{Pd}\left(\eta^{2}-\mathrm{TTF}\right)\right]$ (or bis- $\eta^{2}$ complex $\left.\left[\left(\mathrm{PPh}_{3}\right)_{2} \mathrm{Pd}\left(\eta^{2}-\mathrm{TTF}-\eta^{2}\right) \mathrm{Pd}\left(\mathrm{PPh}_{3}\right)_{2}\right]\right)$ does not seem unlikely, all the more since when we heated $\mathrm{Me}_{4}$-TTF (TMTTF), with both double bonds substituted by methyl groups, with $\mathrm{Pd}\left(\mathrm{PPh}_{3}\right)_{4}$ in toluene no dithiolene complex was formed and only the precipitation of black colloidal Pd was observed. The same result was obtained when TTFtetra(methylcarboxylate) (TTF(COOMe $\left.)_{4}\right)$, an electron poorer donor, was heated in the presence of $\operatorname{Pd}\left(\mathrm{PPh}_{3}\right)_{4}$. In such hypothesized $\eta^{2}$ complex, [( $\left.\left.\mathrm{PPh}_{3}\right)_{2} \mathrm{Pd}\left(\eta^{2}-\mathrm{TTF}\right)\right]$, the Pd center, perpendicular to the TTF mean plane, would be in favorable situation to interact with the neighboring $S$ atoms and eventually to migrate on them, followed by the insertion in one of the $\mathrm{C}-\mathrm{S}$ bonds. Then a reductive elimination of a carbene species would generate the monomeric $\left[\left(\mathrm{PPh}_{3}\right)_{2} \mathrm{Pd}(\mathrm{edt})\right]$ complex which further dimerizes in the reaction conditions, upon loss of a phosphine ligand, to afford the most stable species 1 .

As already mentioned, the complex $\mathbf{1}$ was obtained as a dark violet crystalline solid. Solutions of $\mathbf{1}$ in methylene 


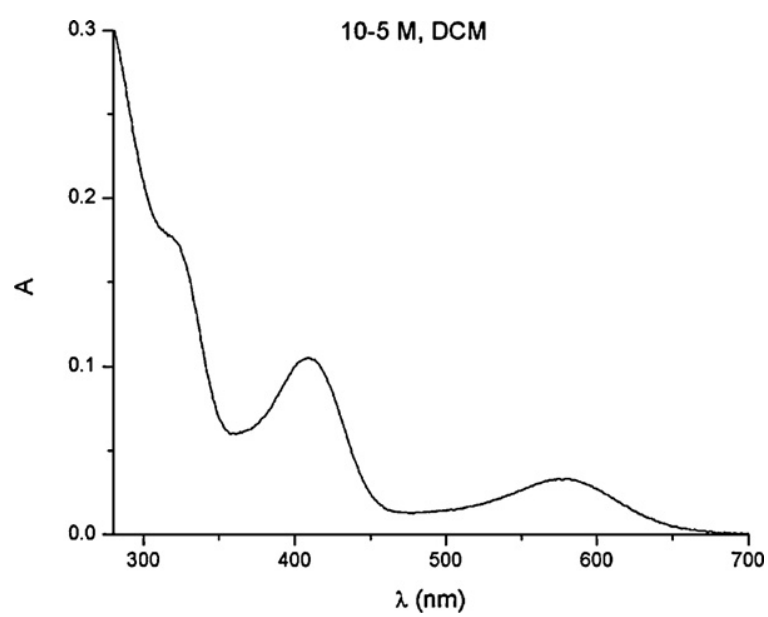

Fig. 1. UV-Vis spectra of $\left[\left(\mathrm{Ph}_{3} \mathrm{P}\right) \mathrm{Pd}(\mathrm{edt})\right]_{2}(\mathbf{1})\left(\lambda_{\max }=576 \mathrm{~nm}, \varepsilon=3270\right.$ $\left.\mathrm{L} \cdot \mathrm{mol}^{-1} \cdot \mathrm{cm}^{-1}, \mathrm{c}=10^{-5} \mathrm{M}\right)$.

chloride are stable to air and have an intense violet greenish color. UV-Visible spectra of $\mathrm{CH}_{2} \mathrm{Cl}_{2}$ solutions of $\mathbf{1}$ (Fig. 1) clearly show a low energy absorption band at $\lambda=576 \mathrm{~nm}\left(\varepsilon=3270 \mathrm{~L} \cdot \mathrm{mol}^{-1} \cdot \mathrm{cm}^{-1}\right)$ and a more intense one at $\lambda=408 \mathrm{~nm}\left(\varepsilon=10,470 \mathrm{~L} \cdot \mathrm{mol}^{-1} \cdot \mathrm{cm}^{-1}\right)$.

The lowest energy band thus appears at higher energy when compared to the neutral bis(dithiolene) complex $\left[\operatorname{Pd}(\text { edt })_{2}\right](\lambda=785 \mathrm{~nm}[5 \mathrm{~b}])$, for which the nature of the corresponding electronic transition has been well documented.

Cyclic voltammetry measurements on $\mathbf{1}$ show only an irreversible oxidation peak at $0.80 \mathrm{~V}$ vs SCE.

\subsection{Structural analysis of $\left[\left(P h_{3} P\right) P d(e d t)\right]_{2}(1)$}

The final proof for the dimeric structure of $\mathbf{1}$ was provided by a single crystal X-ray analysis. Suitable crystals have been grown either by slow evaporation of toluene from a solution of $\mathbf{1}$, or by slow diffusion of methanol onto a solution of $\mathbf{1}$ in $\mathrm{CH}_{2} \mathrm{Cl}_{2}$. In both cases the complex crystallizes in the monoclinic system, space group $\mathrm{C} 2 / \mathrm{c}$, with one independent half of molecule of complex in the unit cell, the other half being generated through the inversion center, and one molecule of solvent disordered over the inversion center (Fig. 2). With the exception of the solvent molecule $\left(\mathrm{CH}_{2} \mathrm{Cl}_{2}\right.$ versus $\left.\mathrm{C}_{7} \mathrm{H}_{8}\right)$ the two structures are identical, therefore only the structural parameters of the $\mathrm{CH}_{2} \mathrm{Cl}_{2}$ solvate will be detailed hereafter.

Each Pd atom is surrounded by one P atom, one $\mu_{1} \mathrm{~S}$ atom (S2) and two bridging $\mu_{2}$ S atoms (S1 and S1') within a slightly distorted square planar geometry, as shown by the bond angles around the metal center (Table 1). Pd-S bond lengths range between 2.30 and $2.36 \AA$, the longest one being that with the bridging $S$ atom belonging to the neighboring dithiolene ligand.

The central $\left[\mathrm{Pd}_{2} \mathrm{~S}_{2}\right]$ metallacycle is highly folded about the $\mathrm{S} 1 \cdots \mathrm{S} 1^{\prime}$ hinge, the corresponding torsion angle amounting to $67.9^{\circ}$ (Fig. 3), while the metalla-dithiolene rings are practically planar. Note the values for the dihedral angles between the two five-membered metallacycles $\left(83.5^{\circ}\right)$, and also between the least-squares plane 5 atoms Pd1, S2, C2, C1, S1 and least-squares plane 3 atoms Pd1, S1, $\operatorname{Pd}^{\prime}\left(57.3^{\circ}\right)$. An interesting feature lies on the very short distance between one vinylic proton of each dithiolene ligands ( $\mathrm{H} 1$ and $\mathrm{H} 7$, respectively) and the centroid of a phenyl ring (as highlighted in Fig. 2), very likely providing a strong shielding of these protons in the ${ }^{1} \mathrm{H}$ NMR spectrum (vide supra).

This suggests, together with the single resonance measured in ${ }^{31}$ P NMR spectroscopy, that the configuration observed in the solid state is rigid and very likely preserved also in solution at room temperature. On the contrary, in the case of the saturated analogue $\left[\left(\mathrm{Ph}_{3} \mathrm{P}\right) \mathrm{Pd}(\right.$ ethanedithiolate) $]_{2}$ (with dithiolate ligands instead of dithiolenes), described by Hong [16], two singlets were observed in the ${ }^{31} \mathrm{P}$ NMR spectrum in solution in spite of the symmetrical coordination of the two phosphines, as shown by single crystal X-ray analysis. The authors suggested that this behaviour was likely due to an equilibrium between two conformations in solution. Note that this saturated
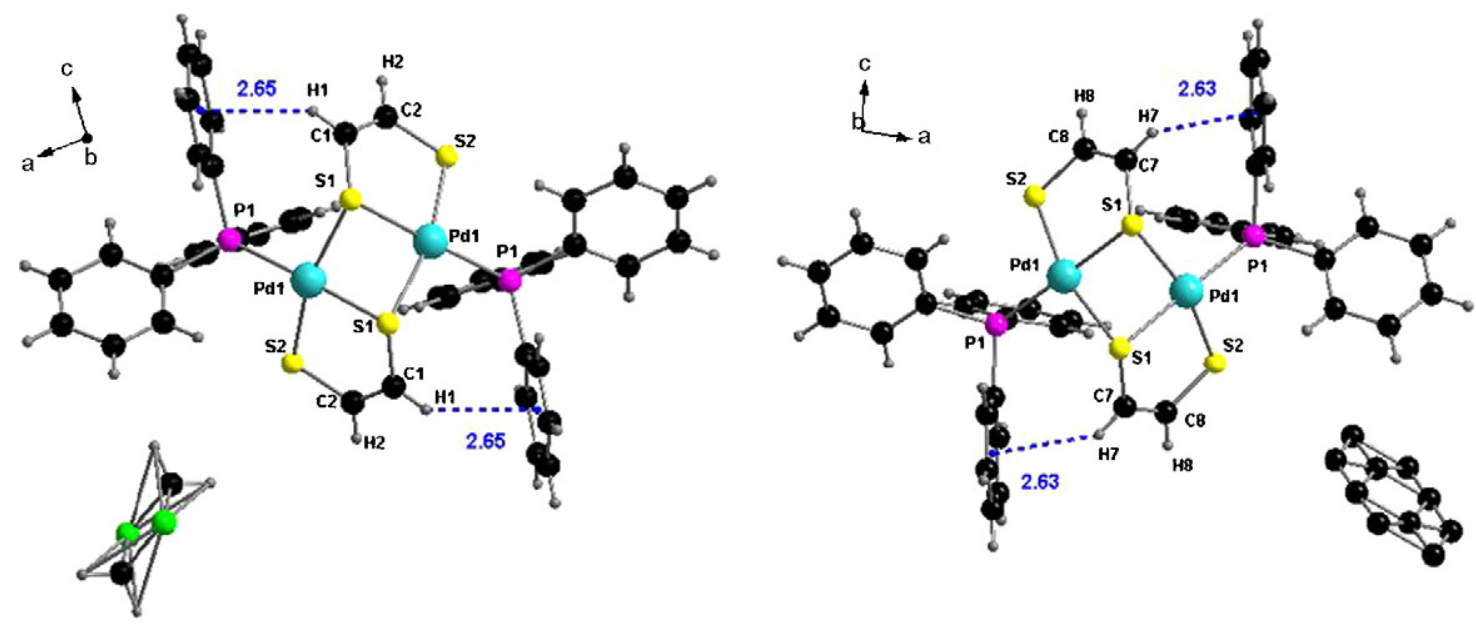

Fig. 2. Molecular structure of $\left[\left(\mathrm{Ph}_{3} \mathrm{P}\right) \mathrm{Pd}(\text { edt })\right]_{2} \bullet \mathrm{CH}_{2} \mathrm{Cl}_{2}$ (left) and $\left[\left(\mathrm{Ph}_{3} \mathrm{P}\right) \mathrm{Pd}(\text { edt })\right]_{2} \bullet \mathrm{PhCH}_{3}$ (right). 
Table 1

Selected lengths $(\AA)$ and angles $\left(^{\circ}\right)$ for compound $\mathbf{1}$

\begin{tabular}{|c|c|c|c|c|c|}
\hline & Distances $(\AA)$ & & Angles $\left({ }^{\circ}\right)$ & & Dihedral angles $\left({ }^{\circ}\right)$ \\
\hline $\operatorname{Pd}(1) \ldots \operatorname{Pd}\left(1^{\prime}\right)$ & $2.9825(6)$ & $S(1)-\operatorname{Pd}(1)-S\left(1^{\prime}\right)$ & 79.99(3) & $\operatorname{Pd}(1)-S(1)-S\left(1^{\prime}\right)-\operatorname{Pd}\left(1^{\prime}\right)$ & 67.9 \\
\hline $\mathrm{Pd}(1)-\mathrm{S}(1)$ & $2.3300(6)$ & $S(1)-P d(1)-S(2)$ & $88.75(3)$ & & \\
\hline $\operatorname{Pd}(1)-S(2)$ & $2.3001(7)$ & $\mathrm{S}(2)-\mathrm{Pd}(1)-\mathrm{P}(1)$ & $90.15(2)$ & & \\
\hline $\operatorname{Pd}(1)-S\left(1^{\prime}\right)$ & $2.3637(6)$ & $\mathrm{P}(1)-\mathrm{Pd}(1)-\mathrm{S}\left(1^{\prime}\right)$ & $101.30(2)$ & & \\
\hline $\mathrm{Pd}(1)-\mathrm{P}(1)$ & $2.2862(6)$ & & & & \\
\hline$C(1)-C(2)$ & $1.317(4)$ & & & & \\
\hline$S(1)-C(1)$ & $1.759(3)$ & & & & \\
\hline$S(2)-C(2)$ & $1.741(3)$ & & & & \\
\hline
\end{tabular}

$\left[\left(\mathrm{Ph}_{3} \mathrm{P}\right) \mathrm{Pd}(\mathrm{edt})\right]_{2} \cdot \mathrm{CH}_{2} \mathrm{Cl}_{2} \ldots \ldots . . .^{\prime}=-x+1, y,-z+1 / 2$.

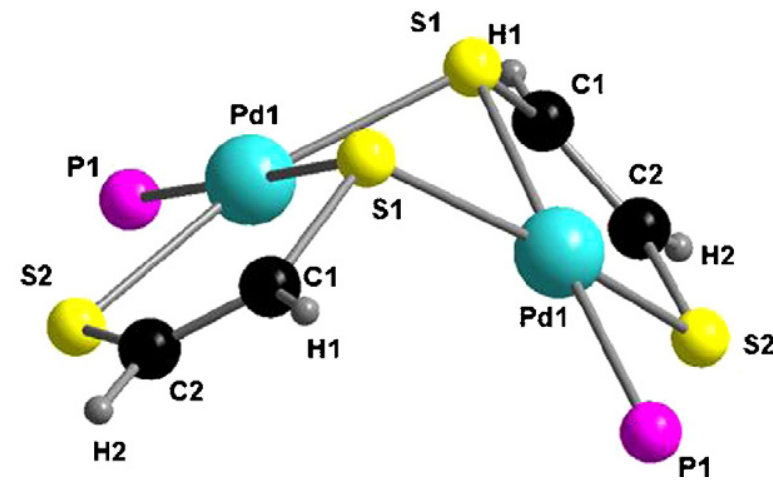

Fig. 3. The central motif in the structure of $\left[\left(\mathrm{Ph}_{3} \mathrm{P}\right) \mathrm{Pd}(\mathrm{edt})\right]_{2} \bullet \mathrm{CH}_{2} \mathrm{Cl}_{2}$ with an emphasis on the folding of the $\left[\mathrm{Pd}_{2} \mathrm{~S}_{2}\right]$ metallacycle. Phenyl rings have been omitted for clarity.

bis(dithiolate) complex adopts in the solid state a similar folded conformation to our complex 1, with comparable bond lengths and angles around the Pd centers.

The dimeric units in the structure of $\left[\left(\mathrm{Ph}_{3} \mathrm{P}\right) \mathrm{Pd}\right.$ (edt) $]_{2} \bullet \mathrm{CH}_{2} \mathrm{Cl}_{2}$ stack in a zipper motif (Fig. 4), with some short perpendicular $\mathrm{CH}_{\text {vinyl }} \cdots \mathrm{Ph}$ and $\mathrm{CH}_{\mathrm{Ph}} \ldots \mathrm{Ph}$ contacts (3.6-3.8 $)$.

\subsection{Theoretical study on $\left[\left(\mathrm{Ph}_{3} P\right) P d(e d t)\right]_{2}(1)$}

In order to investigate on the conformation of $\mathbf{1}$ in the gas phase, hence in the absence of any intermolecular or packing interactions occurring in the solid state, and also to assign the electronic transitions observed in the UV-Visible spectrum, theoretical calculations have been performed at the DFT level, with the PBE0 functional [17] and LanL2dz for Pd and D95 for the other elements as basis set [18]. The optimized geometry is in excellent agreement with the experimental one determined by X-ray analysis, especially when considering the value of the folding angle about the central $\mu \mathrm{S} \cdots \mu \mathrm{S}$ hinge (Table 2 ).

The analysis of the frontier orbitals of the complex $\mathbf{1}$ reveals that the occupied HOMO and HOMO-1 develop mainly on the edt ligands ( $83 \%$ and $87 \%$, respectively), including the participation of the ethylene bridge, with a significant contribution of the metal centers $\left(14 \% \mathrm{~d}_{\mathrm{z}}{ }^{2}\right.$ orbital and $10 \% \mathrm{~d}_{\mathrm{xz}}$ orbital, respectively), while in the LUMO and LUMO+1 the contribution of the metal orbitals

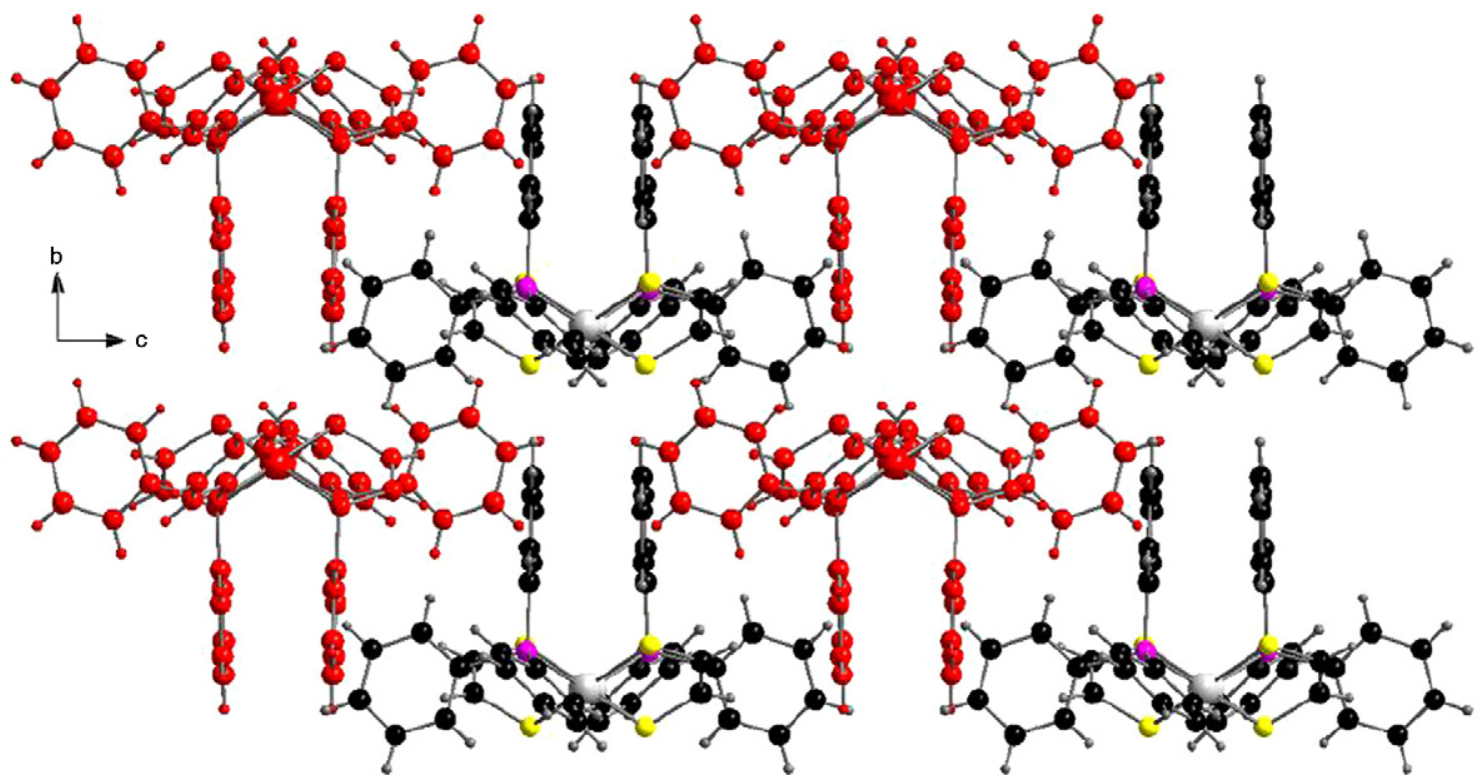

Fig. 4. Zipper type stacking in the $b c$ plane in the structure of $\left[\left(\mathrm{Ph}_{3} \mathrm{P}\right) \mathrm{Pd}(\mathrm{edt})\right]_{2} \bullet \mathrm{CH}_{2} \mathrm{Cl}_{2}$. 
Table 2

Experimental and calculated geometrical parameters for compound $\mathbf{1}$.

\begin{tabular}{lll}
\hline Parameter & Exp. $(\AA)$ & Calc. $(\AA)$ \\
\hline $\mathrm{d}(\mu \mathrm{S}-\mathrm{Pd})$ & 2.330 & 2.412 \\
& 2.364 & 2.467 \\
$\mathrm{~d}(\mathrm{~S}-\mathrm{Pd})$ & 2.300 & 2.388 \\
$\mathrm{~d}(\mathrm{P}-\mathrm{Pd})$ & 2.286 & 2.377 \\
$\mathrm{~d}(\mathrm{Pd} \cdots \mathrm{Pd})$ & 2.983 & 3.015 \\
$\mu \mathrm{S}-\mathrm{Pd}-\mu \mathrm{S}$ & $80.0^{\circ}$ & $79.6^{\circ}$ \\
$\mathrm{Pd}-\mu \mathrm{S}-\mu \mathrm{S}-\mathrm{Pd}$ & $67.9^{\circ}$ & $73.0^{\circ}$ \\
\hline
\end{tabular}

Table 3

Calculated energies of frontier orbitals and their composition according to a Mulliken population analysis.

\begin{tabular}{llllc}
\hline MO & $\mathrm{eV}$ & $\% \mathrm{Pd}$ & $\% \mathrm{dt}$ & $\% \mathrm{PPh}_{3}$ \\
\hline LUMO+1 & -1.89 & 36 & 48 & 17 \\
LUMO & -2.37 & 34 & 48 & 18 \\
HOMO & -5.23 & 14 & 83 & 2 \\
HOMO-1 & -5.39 & 10 & 87 & 3 \\
\hline
\end{tabular}

$\left(\mathrm{d}_{\mathrm{x}}^{2}-\mathrm{y}\right)$ is much more important (34\% and 36\%, respectively), while that of the edt ligands still remains consistent ( $48 \%$ in both orbitals) (Tables 3 and 4 ).

Moreover, TD-DFT, despite the relatively small basis set, reproduces well the experimental UV-Visible spectrum (Fig. 5) and allowed us to identify the orbitals involved in the corresponding electronic transitions (Table 5).

Accordingly, the major component of the lowest energy band is the HOMO $\rightarrow$ LUMO transition, while the HOMO$1 \rightarrow$ LUMO +1 transition is mainly responsible for the next band, in both cases mixed metal-dithiolene ligands being involved.
In conclusion we have synthesized through an unusual reaction between TTF and $\mathrm{Pd}\left(\mathrm{PPh}_{3}\right)_{4}$ the unprecedented dimeric $\mathrm{Pd}$-dithiolene complex $\left[\left(\mathrm{Ph}_{3} \mathrm{P}\right) \mathrm{Pd}(\mathrm{edt})\right]_{2}$, having a rigid folded structure of the central $\left[\mathrm{Pd}_{2} \mathrm{~S}_{2}\right]$ ring, as shown by single crystal X-ray structure and NMR. In spite of the fact that neither the metals nor the dithiolene ligands are oxidized in this complex, it shows a rather low energy absorption band. Theoretical calculations at the TD-DFT level support the assignment of this band mainly to the HOMO $\rightarrow$ LUMO transition, while the frontier orbitals are clearly combinations of metal and dithiolene orbitals.

\section{Experimental}

\subsection{General}

Reactions were carried out under Argon and using toluene HPLC. Nuclear magnetic resonance spectra were recorded on a Bruker Avance DRX 500 spectrometer (operating at $500.04 \mathrm{MHz}$ for ${ }^{1} \mathrm{H}, 125 \mathrm{MHz}$ for ${ }^{13} \mathrm{C}$ and 202.39 MHz for ${ }^{31} \mathrm{P}$ ). Chemical shifts are expressed in parts per million (ppm) downfield from external TMS. The following abbreviations are used: $s$; singlet and $\mathrm{m}$; multiplet. MALDI- TOF MS spectra were recorded on Bruker Biflex-IIITM apparatus; equipped with a $337 \mathrm{~nm}$ N2 laser. Elemental analyses were recorded using Flash 2000 Fisher Scientific Thermo Electron analyzer. IR spectra were recorded on Bruker FT-IR Vertex 70 spectrometer equipped with a Platinum diamond ATR accessory.

\subsection{Synthesis of $\left[\left(\mathrm{Ph}_{3} \mathrm{P}\right) \mathrm{Pd}(\mathrm{edt})\right]_{2} 1$}

To a degassed solution of tetrathialfulvalene (102 mg, $0.5 \mathrm{mmol})$ in $10 \mathrm{ml}$ of toluene, $\mathrm{Pd}\left(\mathrm{PPh}_{3}\right)_{4}(600 \mathrm{mg}$,

Table 4

Representation of selected molecular orbitals with an isovalue of 0.05 .

MO MO

LUMO

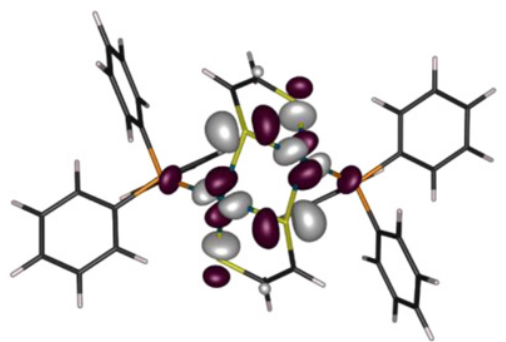

HOMO

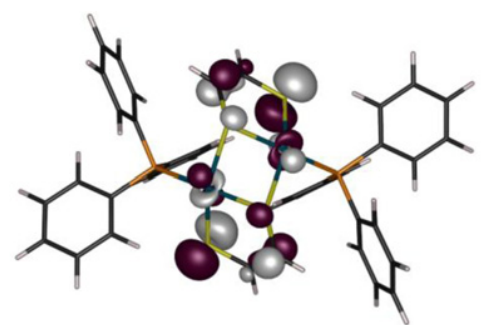

LUMO+1

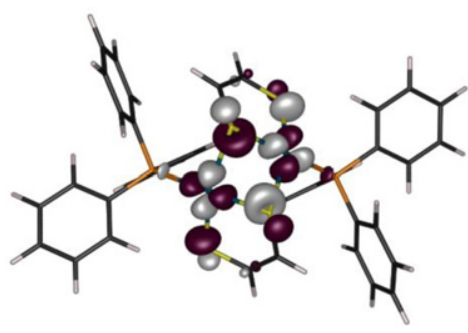

HOMO-1

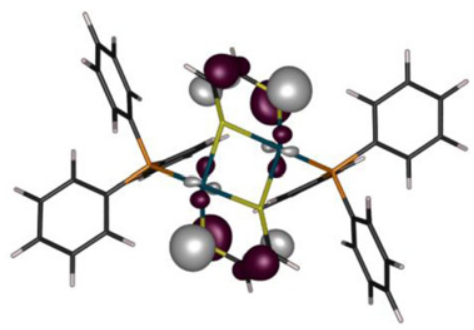




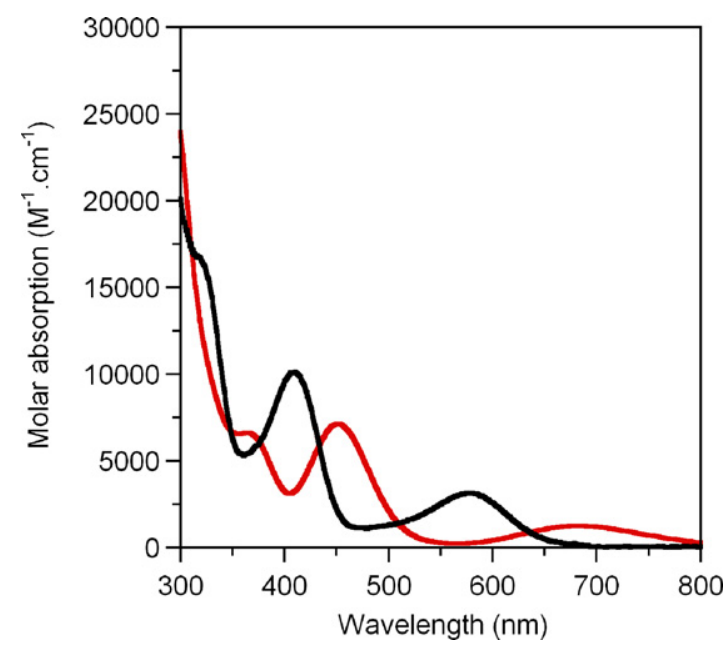

Fig. 5. Experimental (black) and theoretical (red) absorption spectra.

$0.5 \mathrm{mmol}$ ) was added and the mixture was stirred at reflux for $48 \mathrm{~h}$. After cooling the solution was filtered over a path of silica and washed with dichloromethane. After the removal of the solvents the crude was purified by chromatography using as eluent a mixture of hexane/ dichloromethane $1 / 1$ followed by dichloromethane. Black rhombohedral crystals were obtained by slow diffusion of methanol in a dichloromethane solution of the compound, or by slow evaporation of toluene.

Yield: 5\%. ${ }^{1} \mathrm{H}-\mathrm{NMR}\left(500 \mathrm{MHz}, \mathrm{CDCl}_{3}\right.$ ) $\delta / \mathrm{ppm}: 4.46(\mathrm{~m}$, $2 \mathrm{H}), 5.30$ (s, $\left.0.7 \mathrm{H}, \mathrm{CH}_{2} \mathrm{Cl}_{2}\right), 6.28(\mathrm{~m}, 2 \mathrm{H}), 7.37\left(\mathrm{~m}, 12 \mathrm{H}, \mathrm{H}_{\mathrm{Ph}}\right)$, $7.43\left(\mathrm{~m}, 6 \mathrm{H}, H_{\mathrm{Ph}}\right), 7.67\left(\mathrm{~m}, 12 \mathrm{H}, H_{\mathrm{Ph}}\right)$.

${ }^{13} \mathrm{C}-\mathrm{NMR}\left(125 \mathrm{MHz}, \mathrm{CDCl}_{3}\right) \delta / \mathrm{ppm}: 53.43\left(\mathrm{CH}_{2} \mathrm{Cl}_{2}\right)$, 112.62 (-S-CH-CH-S-), 128.25, 128.29, 128.33, 130.47, $130.85,134.57\left(C_{\mathrm{Ph}}\right), 147.80$ (-S-CH-CH-S-).

${ }^{31} \mathrm{P}-\mathrm{NMR}\left(202 \mathrm{MHz}, \mathrm{CDCl}_{3}\right.$ ) $\delta / \mathrm{ppm}: 30.26$.

MS (MALDI-TOF): $m / z: 917.60\left(\mathrm{M}_{\mathrm{th}}=917.75\right)$.

Elemental analysis calcd. (\%) for $\mathrm{C}_{40} \mathrm{H}_{34} \mathrm{P}_{2} \mathrm{Pd}_{2} \mathrm{~S}_{4}$ : C, 52.35; H, 3.73; P, 6.75; Pd, 23.19; S, 13.98; found: C, 51.69; H, 3.65; S, 13.99 .

IR (ATR) $\mathrm{cm}^{-1}: 1516,1479,1433,1094,997,802,745$, 687, 524, 505, 436.

\subsection{X-ray structure determinations}

Details about data collection and solution refinement are given in Table 6. X-ray diffraction measurements were

Table 5

TD-DFT calculated energies and assignment of the most pertinent electronic excitations over $300 \mathrm{~nm}$.

\begin{tabular}{|c|c|c|c|c|}
\hline $\begin{array}{l}\text { Excited } \\
\text { state }\end{array}$ & $\begin{array}{l}\text { Wavenumber } \\
\left(\mathrm{cm}^{-1}\right)\end{array}$ & $\begin{array}{l}\lambda \\
(\mathrm{nm})\end{array}$ & Osc. & Transition \\
\hline 1 & 14,660 & 682 & 0.017 & HOMO $\rightarrow$ LUMO (82\%) \\
\hline 6 & 21,933 & 456 & 0.084 & $\begin{array}{l}\text { HOMO- } 1 \rightarrow \text { LUMO + } 1(68 \%) \\
\text { HOMO- } 4 \rightarrow \text { LUMO }(14 \%) \\
\text { HOMO } \rightarrow \text { LUMO }(10 \%)\end{array}$ \\
\hline 10 & 26,810 & 373 & 0.075 & $\begin{array}{l}\text { HOMO-6 } \rightarrow \text { LUMO }(64 \%) \\
\text { HOMO-19 } \rightarrow \text { LUMO + } 1 \text { (6\%). . }\end{array}$ \\
\hline 11 & 28,966 & 345 & 0.040 & $\begin{array}{l}\text { HOMO-3 } \rightarrow \text { LUMO + } 1 \text { (21\%), } \\
\text { HOMO-19 } \rightarrow \text { LUMO }(18 \%) . .\end{array}$ \\
\hline
\end{tabular}

Table 6

Crystallographic data, details of data collection and structure refinement parameters.

\begin{tabular}{lll}
\hline & {$\left[\left(\mathrm{Ph}_{3} \mathrm{P}\right) \mathrm{Pd}(\mathrm{edt})\right]_{2} \bullet \mathrm{CH}_{2} \mathrm{Cl}_{2}$} & {$\left[\left(\mathrm{Ph}_{3} \mathrm{P}\right) \mathrm{Pd}(\mathrm{edt})\right]_{2} \bullet \mathrm{PhCH}_{3}$} \\
\hline Formula & $\mathrm{C}_{20.50} \mathrm{H}_{18} \mathrm{Cl} \mathrm{P} \mathrm{Pd} \mathrm{S}_{2}$ & $\mathrm{C}_{23.50} \mathrm{H}_{17} \mathrm{P} \mathrm{Pd} \mathrm{S}_{2}$ \\
$M\left[\mathrm{gmol}^{-1}\right]$ & 501.29 & 500.86 \\
$T[\mathrm{~K}]$ & $293(2)$ & $293(2)$ \\
Crystal system & Monoclinic & Monoclinic \\
Space group & $\mathrm{C} 2 / \mathrm{c}$ & $\mathrm{C} 2 / \mathrm{c}$ \\
$a[\AA]$ & $27.042(5)$ & $27.6952(13)$ \\
$b[\AA]$ & $9.4680(14)$ & $9.6533(9)$ \\
$c[\AA]$ & $16.2415(9)$ & $16.2542(17)$ \\
$\alpha\left[{ }^{\circ}\right]$ & 90.00 & 90.00 \\
$\beta\left[{ }^{\circ}\right]$ & $94.757(7)$ & $95.387(6)$ \\
$\gamma\left[{ }^{\circ}\right]$ & 90.00 & 90.00 \\
$V\left[\AA^{3}\right]$ & $4144.0(10)$ & $4326.4(6)$ \\
$Z$ & 8 & 8 \\
$\rho_{\text {calcd }}\left[\mathrm{gcm}{ }^{-3}\right]$ & 1.607 & 1.538 \\
$\mu\left[\mathrm{mm}^{-1}\right]$ & 1.305 & 1.131 \\
Goodness-of-fit & 1.065 & 1.090 \\
$\quad$ on $\mathrm{F}^{2}$ & & \\
Final R1/wR2 & $0.0333 / 0.0762$ & $0.0233 / 0.0485$ \\
$\quad[\mathrm{I}>2 \sigma(\mathrm{I})]$ & & $0.0387 / 0.0554$ \\
$\mathrm{R} 1 / w \mathrm{R} 2$ & $0.0646 / 0.0903$ & \\
$\quad($ all data $)$ & & \\
\hline
\end{tabular}

performed on a Bruker Kappa CCD diffractometer, operating with a $\mathrm{Mo}_{\mathrm{K} \alpha}(\lambda=0.71073 \AA) \mathrm{X}$-ray tube with a graphite monochromator. The structures were solved (SHELXS-97) by direct methods and refined (SHELXL-97) by full matrix least-square procedures on $\mathrm{F}^{2}$ [19]. All nonhydrogen atoms were refined anisotropically. Hydrogen atoms were introduced at calculated positions (riding model), included in structure factor calculations but not refined. Crystallographic data for the two structures have been deposited with the Cambridge Crystallographic Data Centre, deposition number CCDC $866362\left(\left[\left(\mathrm{Ph}_{3} \mathrm{P}\right) \mathrm{Pd}(\mathrm{edt})\right]_{2} \bullet \mathrm{PhCH}_{3}\right)$ and CCDC $866363\left(\left[\left(\mathrm{Ph}_{3} \mathrm{P}\right) \mathrm{Pd}(\mathrm{edt})\right]_{2} \bullet \mathrm{CH}_{2} \mathrm{Cl}_{2}\right)$. These data can be obtained free of charge from CCDC, 12 Union road, Cambridge CB2 1EZ, UK (deposit@ccdc.cam.ac.uk or http://www.ccdc.cam.ac.uk).

\subsection{Theoretical calculations}

An optimized geometry, starting from the X-Ray data, has been obtained with the Gaussian09 [20] package at the DFT level of theory. The PBE0 functional [17] with the LanL2dz for Pd and D95 for the other elements basis set has been used [18]. Vibrations frequency calculations performed on the optimized structures at the same level of theory yielded only positive values. TD-DFT calculations for the first 50 singlet excited states have been performed at the same level of theory on the equilibrium geometry.

\subsection{Cyclic voltammetry measurements}

Cyclic voltammetry measurements were carried out with a Biologic SP-150 potentiostat under nitrogen by using a three-electrode cell equipped with a platinum millielectrode of $0.126 \mathrm{~cm}^{2}$ area, an $\mathrm{Ag} / \mathrm{Ag}+$ pseudoreference electrode and a platinum wire counter electrode. The potential values were then re-adjusted with respect to the saturated calomel electrode (SCE). The electrolytic media involved a $0.1 \mathrm{~mol} / \mathrm{L}$ solution of $\left(n \mathrm{Bu}_{4} \mathrm{~N}\right) \mathrm{PF}_{6}$ in 
dichloromethane/acetonitrile 4/1. All experiments were performed at room temperature at $0.1 \mathrm{~V} / \mathrm{s}$.

\section{Acknowledgements}

Financial support from the National Agency for Research (ANR, Project 09-BLAN-0045-01), the University of Angers and the Région Pays de la Loire (grant to D.B.), and the CNRS is gratefully acknowledged.

\section{References}

[1] (a) N. Robertson, L. Cronin, Coord. Chem. Rev. 227 (2002) 93 (b) C.L. Beswick, J.M. Schulman, E.I. Stiefel, Prog. Inorg. Chem. 52 (2004) 55. [2] R. Kato, Chem. Rev. 104 (2004) 5319.

[3] (a) M. Bousseau, L. Valade, J.-P. Legros, P. Cassoux, M. Garbauskas, L.V. Interrante, J. Am. Chem. Soc. 108 (1986) 1908;

(b) A.M. Madalan, N. Avarvari, M. Fourmigué, R. Clérac, L.F. Chibotaru, S. Clima, M. Andruh, Inorg. Chem 47 (2008) 940.

[4] (a) U.T. Mueller-Westerhoff, D.I. Yoon, K. Plourde, Mol. Cryst. Liq. Cryst. 183 (1990) 291;

(b) U.T. Mueller-Westerhoff, B. Vance, D.I. Yoon, Tetrahedron 47 (1991) 909.

[5] (a) G.N. Schrauzer, V.P. Mayweg, J. Am. Chem. Soc. 87 (1965) 3585;

(b) K.W. Browall, L.V. Interrante, J. Coord. Chem. 3 (1973) 27

(c) F. Bigoli, P. Deplano, F.A. Devillanova, V. Lippolis, P.J. Lukes, M.L. Mercuri, M.A. Pellinghelli, E.F. Trogu, J. Chem. Soc., Chem. Commun. (1995) 371;

(d) F. Bigoli, P. Deplano, F.A. Devillanova, J.R. Ferraro, V. Lippolis, P.J. Lukes, M.L. Mercuri, M.A. Pellinghelli, E.F. Trogu, Inorg. Chem. 36 (1997) 1218;

(e) M.C. Aragoni, M. Arca, F. Demartin, F.A. Devillanova, A. Garau, F. Isaia, F. Lelj, V. Lippolis, G. Verani, J. Am. Chem. Soc. 121 (1999) 7098.

[6] C. Lauterbach, J. Fabian, Eur. J. Inorg. Chem. (1999) 1995.

[7] M.C. Aragoni, M. Arca, F.A. Devillanova, F. Isaia, V. Lippolis, A. Manchini, L. Pala, G. Verani, T. Agostinelli, M. Caironi, D. Natali, M. Sampietro, Inorg. Chem. Commun. 10 (2007) 191

[8] (a) S. Olivier, C. Winter, Adv. Mater. 4 (1992) 119;

(b) C.S. Winter, S.N. Olivier, J.D. Rush, C.A.S. Hill, A.E. Underhill, Mol. Cryst. Liq. Cryst. 235 (1993) 181.

[9] N. Kuramoto, K. Asao, Dyes Pigm. 12 (1990) 65.

[10] (a) T.D. Anthopoulos, S. Setayesh, E. Smits, M. Cölle, E. Cantatore, B. de Boer, P.W.M. Blom, D.M. de Leeuw, Adv. Mater. 18 (2006) 1900; (b) T. Taguchi, H. Wada, T. Kambayashi, B. Noda, M. Goto, T. Mori, K Ishikawa, H. Takezoe, Chem. Phys. Lett. 421 (2006) 395.

[11] K.W. Browall, L.V. Interrante, J.S. Kasper, J. Am. Chem. Soc. 93 (1971) 6289.

[12] (a) V.P. Mayweg, G.N. Schrauzer, Chem. Commun. (1966) 640;

(b) G.A. Bowmaker, P.D.W. Boyd, G.K. Campbell, Inorg. Chem. 22 (1983) 1208;

(c) C. Kraffert, D. Walther, K. Peters, O. Lindqvist, V. Langer, J. Sieler, J. Reinhold, E. Hoyer, Z. Anorg. Allg. Chem. 588 (1990) 167;

(d) M. Ebihara, M. Tsuchiya, T. Kawamura, Acta Cryst. C50 (1994) 1880;

(e) K.G. Landis, A.D. Hunter, T.R. Wagner, L.S. Curtin, F.L. Filler, S.A Jansen-Varnum, Inorg. Chim. Acta 282 (1998) 155;

(f) C.E. Keefer, S.T. Purrington, R.D. Bereman, B.W. Knight, D.R. Bedgood Jr., P.D. Boyle, Inorg. Chim. Acta 282 (1998) 200;

(g) C.E. Keefer, R.D. Bereman, S.T. Purrington, B.W. Knight, P.D. Boyle, Inorg. Chem. 38 (1999) 2294;

(h) E. Cerrada, A., Moreno, M., Laguna, Dalton Trans. (2009) 6825

[13] F. Riobé, N. Avarvari, P. Grosshans, H. Sidorenkova, T. Berclaz, M. Geoffroy, Phys. Chem. Chem. Phys. 12 (2010) 9650.

[14] R. Cao, M. Hong, F. Jiang, B. Kang, X. Xie, H. Liu, Polyhedron 15 (1996) 2661.

[15] M.N. Jayaswal, H.N. Peindy, F. Guyon, M. Knorr, N. Avarvari, M. Fourmigué, Eur. J. Inorg. Chem. (2004) 2646.

[16] R. Cao, M. Hong, F. Jiang, H. Liu, Acta Cryst. C 51 (1995) 1280.

[17] C. Adamo, V. Barone, J. Chem. Phys. 110 (1999) 6158.

[18] (a) P.J. Hay, W.R. Wadt, J. Chem. Phys. 82 (1985) 270;

(b) P.J. Hay, W.R. Wadt, J. Chem. Phys. 82 (1985) 284;

(c) P.J. Hay, W.R. Wadt, J. Chem. Phys. 82 (1985) 299.

[19] G.M. Sheldrick, SHELXL91, Release 97-2, Program for the Refinement of Crystal Structures, University of Göttingen, Göttingen, Germany, 1997.

[20] M.J. Frisch, G.W. Trucks, H.B. Schlegel, G.E. Scuseria, M.A. Robb, J.R. Cheeseman, G. Scalmani, V. Barone, B. Mennucci, G.A. Petersson, H. Nakatsuji, M. Caricato, X. Li, H.P. Hratchian, A.F. Izmaylov, J. Bloino, G. Zheng, J.L. Sonnenberg, M. Hada, M. Ehara, K. Toyota, R. Fukuda, J. Hasegawa, M. Ishida, T. Nakajima, Y. Honda, O. Kitao, H. Nakai, T. Vreven, J.A. Montgomery Jr., J.E. Peralta, F. Ogliaro, M. Bearpark, J.J. Heyd, E. Brothers, K.N. Kudin, V.N. Staroverov, R. Kobayashi, J. Normand, K. Raghavachari, A. Rendell, J.C. Burant, S.S. Iyengar, J. Tomasi, M. Cossi, N. Rega, J.M. Millam, M. Klene, J.E. Knox, J.B. Cross, V. Bakken, C. Adamo, J. Jaramillo, R. Gomperts, R.E. Stratmann, O. Yazyev, A.J. Austin, R. Cammi, C. Pomelli, J.W. Ochterski, R.L. Martin, K. Morokuma, V.G. Zakrzewski, G.A. Voth, P. Salvador, J.J. Dannenberg, S. Dapprich, A.D. Daniels, Ö. Farkas, J.B. Foresman, J.V. Ortiz, J. Cioslowski, D.J. Fox, Gaussian 09, Revision A.2, Gaussian, Inc., Wallingford CT, 2009. 